\title{
Morphosyntactical Errors in Students' Recount Text
}

\author{
Atika Nur Alami Harahap ${ }^{1}$, Nurlela ${ }^{2}$, Umar Mono ${ }^{3}$ \\ ${ }^{1,2,3}$ University of Sumatera, Indonesia \\ saiaatika7@gmail.com
}

\begin{abstract}
The aims of the study are to identify the morphosyntactical errors which occur in students' recount text, to describe the most and least of morphosyntactical errors in students' recount text and to explain the reason of morphosyntactical errors occurrence in students' recount text by XI AK at SMK Kartika 1-3 Medan. The primary data are all word, phrases and sentences in students' recount text in the 2020 period. The method used was the qualitative method. The result of the research identified types of morphosyntactical errors; noun morphology, verb morphology, adverb morphology, adjective morphology, noun phrase, verb phrase, word order and transformation. Based the theory used to identify the error is adapted by dulay surface taxonomy, which are; addition, ommission, misorder, and misformation. Misformation of verb morphology is the most frequent error made by the student around $45 \%$ of the total error came from this error and parameter. The second most frequently error are ommission of noun phrase with the total error sum up to $21 \%$, misordering of noun morphology 13\%, addition of verb $11 \%$, addition of word order $8 \%$, the last adverb and adjective morphology 1\%. On the other hand, transformation parameters in all errors didn't occur due to the monotonous of sentences used by student. Almost all the sentences are in the form of declarative sentence with a positive statement form. This research concludes that the student less of information about the use verb 2 in recount text, so they just write what they know and the student confused in used verb especially changed verb 1 into verb 2 in recount text. The reason behind this error is due to 'Misconception' of the student.
\end{abstract}
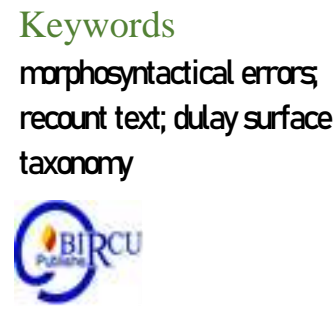

\section{Introduction}

English is the international languages. It plays an important role to communicate with the outside world. In fact, English is very important in the world of work (Ramadani, 2021). English is also used by over one billion people who speak English as their second (or additional) language to communicate with other second language users regardless of different culture and linguistic features (Devy, 2016). In Indonesia, English is learned as subject in scool and it is taught from basic school until university. Dharmawati (2019: 1194) stated that English is one of the subjects included in the curriculum in university, but theoritically the proccess of learning English still cannot achieve the results as expected. This can be evidenced by the fact that there are still many students in the university who are still unable to communicate using English even though they have learned it from entering basic school (SD) to university. One aspects need to be mastered by students is the ability to speak English well, both oral and written. Good English skills must master all four language skills (reading, listening, writing and speaking) and vocabulary and grammar. (Dharmawati, 2021) 
English is one of main important subject that is taught in Senior High School of Indonesia. Based on the Amendment to Government Regulation Number 19 of 2005 concerning National Education Standards in article 70 paragraph 5, is stated English as one of the subjects in National Examination for Senior High School Level. English subject is considered as language learning. The students should learn how to be communicative in speaking English. They learn more speaking skills and develop some attitude toward speaking achievement. Therefore, the speaker must know the topic of the conversation in order to give or share of their information. (Ramadani, et al. 2020).

Nowadays, the government has provided a new curriculum for the vocational high school that is curriculum 2013. Especially for English subject, the reason that the government compose curriculum 2013 is as correction of the previous curriculum and the reality that has happened. The reality is after three years studying English at vocational high school, most students could not get the goal of teaching and learning English at school.

Based on the curriculum, there are four skills of English should be taught, those are: speaking, listening, reading and writing. From the four skills of English which should be taught, the writer focuses on writing. Writing is the most difficult skill to be taught and to be learned for the students. Writing is a means of communication when the students can not express with speech. Therefore, writing is one of activities for the students to express their ideas and feeling in form of written language (Jack and Willy, 2002:303). In writing, the students should master about grammar, have good vocabulary, have an idea, and have to know about the feature of the text itself. Another problem that the students encounter in writing, Sometimes there is an idea energizing in students' mind but it is difficult to express it in written language.

Brown (2001) stated that English teaching and learning process have four skills that are identified as very important; listening, speaking, reading and writing. Teaching writing, especially in English must be considered in the early stages of education, at least, in the Senior High level. It is due to the University level that urges them to write articles in English for international publication regardless of what major they take. Before writing a good scientific article in University level, Senior High student must be able to write various genre of text, including recount text. Recount Text is written out to make a report about an experience of a series of related event (Knapp and Watkins, 2005:224). A recount text has a social function to retell an event with a purpose to inform or entertain the readers (Siahaan and Shinoda, 2008:9).

Dulay et al. (1982:146) mentioned that there are three most useful and commonly used bases for the descriptive classification of error. Those are: 1) linguistic category which classifies errors according to either or both the language component or the particular linguistic constituent the error affects. 2) Surface strategy taxonomy which emphasizes on the surfaces structure such as omission, addition, misformation, and misordering. 3)Comparative analysis which is based on comparison between the structure of the second language error and certain other perspective of their effect on the listener and reader. It focuses on distinguishing errors that seem to cause miscommunication and those that do not.

In the recount text, it is often found morphosyntax error. Morphosyntax is a term used in linguistic studying the application of morphology and syntax on grammatical categories. In short, morphosyntax is the combination between morphological and syntactic studies. Morphology is scientific study about word structure and formation rules. Morphology relates to the construction of words and parts of words. Morphology is the 
identification, analysis, and description, of the structure of word (word as units in the lexicon are the subject matter of lexicology).

The term syntax has been defined by many linguists. Chomsky (2002:1) stated that Syntax is the study of the principles and processes by which sentences are constructed in particular languages. Ba'dulu (2004:45) defines syntax as the study of the rules governing the way words are combined to form sentences in a language. In this use, syntax is opposed to morphology, the study of word structure. Crane et al. (1981:102) defines syntax as the way words put together to form phrase and sentences. To study syntax is to study the patterns and relationship of words, phrases, and clauses.

Based on pre-research, in an informal interview to the teacher of English of SMK Kartika 1-3 Medan, the teacher said that students have ability in writing text, but sometimes they still have errors of their writing such as recount text. Their errors on writing formed in using tenses, incomplete paragraph organization and limited idea exploring. Thus, it brings them having low score in writing class due to the lack of their understanding in creating good writing. Based on the explanation above, a research regarding on the phenomenon above is urgently needed.

The research focuses on morphosyntacticalerror taxonomy in recount text. Morphosyntactical error taxonomy is the taxonomy based on the misapplication of morphological and syntactical. Here is the example of morphosyntactical error in recount text based on surface structure taxonomy. The example is two french fries and two mocha float, the sentence should be two French fries and two mocha floats, two is a number that showed more than one. It is always by a plural noun so the float should be changed with floats. The sentence is Morphosyntactical error or addition.

The aims of the study are to identify the morphosyntactical errors which occur in students' recount text, to describe the most and least of morphosyntactical errors in students' recount text and to explain the reason of morphosyntactical errors occurrence in students' recount text by XI AK at SMK Kartika 1-3 Medan.

\section{Research Methods}

This research used a qualitative method. This type of research did not apply detail arithmetic calculation or statistic. It contained sentences or description of the objects. More specifically, the approach used in conducting this research is descriptive qualitative research. Cohen (2007:205) stated that descriptive research is concerned with conditions or relationships that exist; practices that prevail; beliefs, points of views, or attitudes that are held; processes that are going on; effects that are being felt; or trends that are developing. At times, descriptive research was concerned with how what is or what exists is related to some preceding event that has influenced or affected a present condition or event. Thus, this research described the identified morphosyntactical errors from ten students recount text writing test. Presented the most appeared error to the least and elaborated the finding to prevail the reason behind those errors occurrence.

This research used words, phrases, clauses and sentences as the data to analyse. The source of data were ten students writing composition of recount text. Ten students each produced two texts which madea total of twenty texts.

This researchwas conducted in Senior High School of SMK Kartika 1-3 where the researcher collected the data. The students' writing composition of recount text had been done by themon Thursday, 27 February 2020 in the paragraph writing class. 
The subjects of this research are senior high school students in Medan City or it could be also considered students of English as Foreign Language. Ten students from SMK Kartika 1-3, XI AK class of the second semester, academic year 2019/2020 were taken as the subject. The students of XI AK class are convinced as selected students. According to the English language teacher, these ten students' competences are better than the others. Meanwhile, the object of research are 20 students' recount texts which are derived from the ten students, this means each student produced 2 recount texts.

The method used was the qualitative method. The error analysis was used because it fit with the characteristic of the data and the nature of this research. The analyzing method used in this research is based on Miles, Huberman and Saldana model (2014) interactive model with four phases of data analysis. They were; (1) data collection; (2) data condensation; (3)data display; and (4)conclusion drawing or verification

\section{Results and Discussion}

\subsection{The Description of Morphosyntactical Errors}

The errors were divided based on classification of morphosyntactical error by James; noun morphological error (NME), verb morphological error (VME), adverb morphological error (Adv ME), adjective morphological error (Adj ME), noun phrase error, verb error, word order error, and transformation error.

The table below showed simultaneously morphological and syntactical errors, the findings on morphological errors verb morphological error (VME) is the most dominant $(45 \%)$, then followed by noun morphological error (NME) (13\%), while adverb morphological error (Adv ME) and adjective morphological error (Adj ME) are on the same level (1\%).

Moreover, errors in syntactical were found noun phrase (NP) as the most dominant one $(21 \%)$, followed by verb phrase (VP) $(11 \%)$ and word order $(8 \%)$.

Table 1. Total Calculation of the Errors Found in All Students Writing

\begin{tabular}{|l|l|r|r|r|r|r|r|}
\hline $\begin{array}{l}\text { The } \\
\text { Parameters }\end{array}$ & $\begin{array}{l}\text { Types of } \\
\text { Errors }\end{array}$ & Addition & Ommision & Misformation & Misordering & Total & $\begin{array}{c}\text { Percentage } \\
(\%)\end{array}$ \\
\hline Morphological & NME & & 11 & 1 & 23 & 35 & 13 \\
\hline & VME & & 2 & 109 & 6 & 117 & 45 \\
\hline & Adv ME & & 1 & 1 & 1 & 3 & 1 \\
\hline & Adj ME & & & 1 & 1 & 2 & 1 \\
\hline & Noun Phrase & 12 & 33 & 4 & 5 & 54 & 21 \\
\hline Syntactical & Verb & 11 & 8 & 5 & 4 & 28 & 11 \\
\hline & Word order & 6 & 1 & 1 & 14 & 22 & 8 \\
\hline & Transformation & & & & & & 261 \\
\hline
\end{tabular}

The total error found in twenty students writing identified that Misformation in verb morphology error as the most frequent error made by the student. Around $45 \%$ of the total error came from this error and parameter. The second most frequent error was in Ommission of Noun Phrase with the total error sum up to $21 \%$. On the other hand, Transformation parameters in all errors didn't occur due to the monotonous of sentences used by student. Almost all the sentences were in the form of declarative sentence with a 
positive statement form. The result of this research based on the 20 recount texts written by the students, found VME 45\% was the most dominant. This occurred, when they were writing the texts.They made more errors on morphological errors, that were omission, this happened on verb. On the other hand, transformation parameters in all errors didn't occur due to the monotonous of sentences used by student. Almost all the sentences are in the form of declarative sentence with a positive statement form. This research concludes that the student less of information about the use verb 2 in recount text, so they just write what they know and the student confused in used verb especially changed verb 1 into verb 2 in recount text. The reason behind this error is due to 'Misconception' of the student.

\section{Conclusion}

The result of the research identified types of morphosyntactical errors; noun morphology, verb morphology, adverb morphology, adjective morphology, noun phrase, verb phrase, word order and transformation. Based the theory used to identify the error is adapted by dulay surface taxonomy, which are; addition, ommission, misorder, and misformation. Misformation of verb morphology is the most frequent error made by the student around $45 \%$ of the total error came from this error and parameter. The second most frequently error are ommission of noun phrase with the total error sum up to $21 \%$, misordering of noun morphology $13 \%$, addition of verb $11 \%$, addition of word order $8 \%$, the last adverb and adjective morphology $1 \%$. On the other hand, transformation parameters in all errors didn't occur due to the monotonous of sentences used by student. Almost all the sentences are in the form of declarative sentence with a positive statement form. This research concludes that the student less of information about the use verb 2 in recount text, so they just write what they know and the student confused in used verb especially changed verb 1 into verb 2 in recount text. The reason behind this error is due to 'Misconception' of the student.

Based on the data analysis, research finding and conclusion, this research provided suggestion in the matter of future research and improvement of the teaching of English writing, especially in the most error made by student. The suggestions were:

1. For future research, it is suggested to perform a research regarding student behavior in writing, focusing in the way they make sentences. Because from this research it is identified that most of the student write/compose Simple sentence in the form of declarative of positive statement. This proven by the zero mistakes of Transformation parameters. They don't do error in Transformation parameter because all their sentences are in one form. A research lead to an improvement of student writing skill with various sentences type is recommended.

2. For the improvement of English writing especially in the use of appropriate verb in a sentence and text, teacher should remodel the way of teaching tense. Teaching tense is not only about pattern but it should focus more on why and when we used the tense. For example, in recount text it should be confirmed that past tense is used in most of the sentence, because in recount one is telling a past action or experience. 


\section{References}

Ba'dulu, Abdul Muis. (2004). Introduction to Linguistics. Universitas Negeri Makassar.

Brown, H. D. (2001). Teaching by Principles: An Interactive Approach to Language Pedagogy. San Francisco State University.

Chomsky, Noam. (2002). Syntactic Structures. Berlin: Walter de Gruyter GmbH.

Cohen, L. (2007). Research Method in Education. New York: Routledge Falmer.

Crane, et al. (1981). An Introduction to Linguistics. Canada: Simultaneously.

Dharmawati. (2021). An Analysis of Students' Learning Independence in Learning English for Computer Using Google Classroom. Budapest International Research and Critics Institute-Journal (BIRCI-Journal). P. 1635-1642.

Dulay, Heidi, et al. (1982). Language Two. New York: Oxford University Press.

Jack C. Richard \& Willy A. Renandya. (2002). Methodology in Language Teaching: An Anthology of Current Practice. New York: Cambridge University Press.

Knapp, Peter \& Watkins, Megan. (2005). Genre, Text, Grammar: Technologies for Teaching and Assessing Writing. Australia: New South Wales Press Ltd.

Ramadani, et al. (2020). The Increasing of Students' English Speaking by Using Community Language Learning (CLL) through Students English Association of LP3I (SEAL) at Politeknik LP3I Medan. Budapest International Research and Critics Institute-Journal (BIRCI-Journal). P. 2534-2542

Siahaan, S., \& Shinoda, K. (2008). Generic Text Structure. Yogyakarta: Graha Ilmu. 